\title{
Product Family Design based on Analytic Network Process
}

\author{
Taioun Kim \\ Dept. of Industrial and Management Engineering \\ Kyungsung University \\ (twkim@ks.ac.kr)
}

In order to maintain customer satisfaction and to remain productive and efficient in today's global competition, mass customization is adopted in many leading companies. Mass customization through product family and product platform enables companies to develop new products with flexibility, efficiency and quick responsiveness. Thus, product family strategy based on product platform is well suited to realize the mass customization. Product family is defined as a group of related products that share common features, components, and subsystems; and satisfy a variety of market niches. The objective is to propose a product family design strategy that provides priority weights among product components by satisfying customer requirements. The decision making process for a new product development requires a multiple criteria decision making technique with feedback. An analytical network process is adopted for the decision making modeling and procedure. For the implementation, a netbook product known as a small PC which is appropriate for the product family model is adopted. According to the proposed architecture, the priority weight of each component for each product family is derived. The relationship between the customer requirement and product component is analyzed and evaluated using QFD model.

Received : September 29, 2011 Revision : October 24, 2011 Accepted : December 25, 2011

Type of Submission : English Fast-track Corresponding author : Taioun Kim

\section{Introduction}

In order to develop a new product with flexibility, efficiency and quick responsiveness, mass customization through product family design is highly recommended. As products become more complex, short-life cycled and customized, the design efforts require more knowledge-intensive,

\footnotetext{
* This research was supported by Kyungsung University Research Grants in 2011.
} 
collaborative, coordinating, and information sharing. By sharing knowledge, information, component and process across different families of products, the product realization process will be more efficient, cost-effective and quick-responsive (Martin and Ishii, 2002).

A Product family (PF) is defined as a group of related products that share common features, components, and subsystems; and satisfies a variety of market niches. The PF comprises a set of variables, features or components that remain constant from product to product, and others that vary from product to product. Product platform is the set of parameters (common parameters), features, and/or components that remain constant from product to product, within a given product family. In the product family design approaches, there are two approaches, which are top down (a priori) and bottom-up (a posteriori) approach. In the top-down approach, a company strategically manages and develops family of products based on a product platform and its derivatives. In the bottom-up approach, a company resigns or consolidates a group of distinct products to standardize components to improve economies of scale (Simpson et al., 2001).

In the process of a new product development, Quality Function Deployment (QFD) has been widely adopted to find Customer Requirements (CRs) and transforms them into Product Components (PCs) or engineering characteristics. QFD employs a cross-functional team to determine CRs and translate them into product design through a structured and well documented framework. The relationships in the QFD cells can be transformed through AHP (Analytic Hierarchy Process) methods. AHP has been widely adopted to solve an multi-criteria decision making problem. However, independence is assumed among the decision attributes in the hierarchy. Saaty proposed an ANP (Analytic Network Process) as a more general form of AHP (Saaty, 1999). The ANP is a general theory of relative measurement used to derive composite priority ratio scales from individual ratio scales that represent relative measurements of the influence of elements that interact with respect to control criteria. Through its supermatrix whose elements are themselves matrices of column priorities, the ANP captures the outcome of dependence and feedback within and between clusters of elements. Thus, the ANP incorporates feedback and interdependent relationships among decision attributes and alternatives.

The purpose of this research is to propose an integrated framework for product family modeling based on ANP and QFD. Following the framework, product family analysis has been conducted for the market segment. For the classified PFs, ANP method is applied to find the priority weights for each group. A thorough implementation has been performed to validate the methodology using a real netbook product for the design of product family. Section 2 reviews recent literatures in this area. Section 3 proposes QFD and ANP model adopted in this research. Section 4 performs product family analysis for 
the problem domain. Section 5 illustrates implementation process and results applying the chosen problem in the model. Section 6 compares results from ANP model with QFD framework without dividing PF groups. Section 7 summarizes results and discussions.

\section{Literature Review}

New products must be different from what is already in the market and must meet customer needs more completely. Thus, many companies struggle to provide as much variety for the market as possible with as little variety between products as possible (Simpson et al., 2005). The $\mathrm{PF}$ is realized through the product platform in the new product development process. Kuang and Jiang (2009) proposed a product platform design method based on Kansei engineering for a mobile phone body design. Kim (2010) proposed a PF modeling scheme using web ontology language. The capturing process of product features is based on Formal Concept Analysis (FCA). FCA is a principled way of automatically deriving ontology from the collection of objects and their properties. The method is used for data analysis, knowledge representation and information management. Association rules among product items by association analysis suggest sales effect among products. Chang (2010) proposed a product value evaluation model and applied for the transaction data related to clothing of an online shopping mall.

A new product design idea is conceptua- lized based on functional requirements, which is then realized into a product that fulfills customer requirements through behavior. QFD has been widely adopted for transforming functional requirements into design parameters. Since the focus of QFD is placed on the early stage of a product development, the uncertainty in the input data of QFD is inevitable. To deal with this issue, robust QFD is proposed which is capable of considering the uncertainty in the input data and the resulting variability of the output (Kim and Kim, 2008).

A product market can be partitioned into several market segments, each of which contains a number of customers with homogeneous preferences. QFD and fuzzy optimization methods are proposed to achieve the optimal target settings of engineering characteristics (ECs) of a new product under a multi-segment market (Luo et al., 2010). An integrated optimization model for partitioned market segments based on QFD technology is established to maximize the overall customer satisfaction for the market considering the weights of importance of different segments.

Network research has been used in the analysis of customer relationship management and marketing in the product sales. A bipartite network which is composed of products (node) and its customer (edge) represents the products which a customer has purchased. Kim, et al. (2009) adopted a product network to analyze the sales data in the department store. Recently, a social network analysis method is adopted for a 
new product recommendation (Cho and Bang, 2009). The new products are recommended to the customer according to the relationship among the products based on the centrality concept.

The basic assumption of AHP is the condition of functional independence of the upper part, or cluster, of the hierarchy, from all its lower parts, and from the criteria or items in each level. Saaty (2005) suggested the use of AHP to solve the problem of independence among alternatives or criteria, and the use of ANP to solve the problem of dependence among alternatives or criteria. The ANP is composed of two parts. The first consists of a control hierarchy or network of criteria and subcriteria that control the interactions. The second is a network of influences among the elements and clusters. The network varies from criterion to criterion and a different supermatrix of limiting influence is computed for each control criterion.

The structural difference between AHP and ANP is illustrated in <Figure 1>. A hierarchy has a goal or a source node or cluster. It also has a sink node or cluster representing the alternatives of the decision. Unlike a hierarchy, a network spread out in all directions and its clusters of elements are not arranged in a particular order. A control hierarchy can also be involved in the network itself with feedback involved from the criteria to the elements of the network and back to the criteria to modify their influence. Nodes of the network represent components of the system; arcs denote interaction between them, where the directions of arcs sig- nify directional dependence. For example, $X \rightarrow$ $Y$ means that the elements of a component $Y$ depends on component $X$. Interdependency between two clusters, termed outer dependence, is represented by a two-way arrow. Inner dependencies among the elements of a cluster are represented by looped arcs.
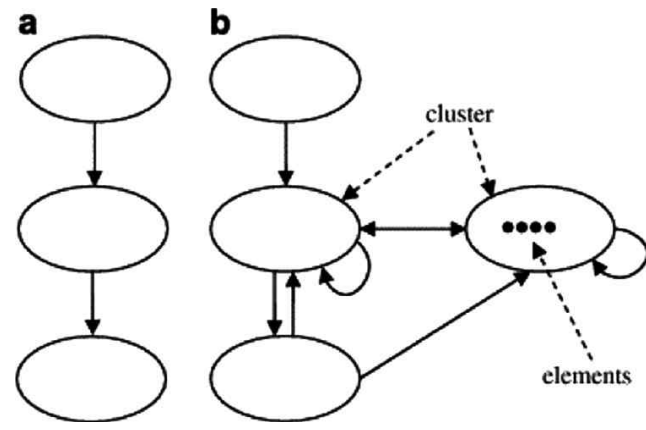

$<$ Figure 1> Structural Difference between a Hierarchy and a Network : (a) a Hierarchy and (b) a Network

Assume that there is a system of m clusters or components, where the elements in each component interact or have an impact on the other elements. The component $\mathrm{h}$, denoted by $\mathrm{C}_{\mathrm{h}}, \mathrm{h}=1, \cdots, \mathrm{m}$, has $\mathrm{n}_{\mathrm{h}}$ elements, that are represented by $\mathrm{e}_{\mathrm{h} 1}, \mathrm{e}_{\mathrm{h} 2}, \cdots, \mathrm{e}_{\mathrm{hnh}}$. A priority vector derived from paired comparisons in a usual way represents the impacts of a given set of elements in a component on another element in the system. When an element has no influence on another element, its influence priority is assigned as zero. A supermatrix is composed of the priority vectors derived from pairwise comparison matrices. An example of supermatrix is shown in $<$ Figure $2>$. The components $\mathrm{C}_{\mathrm{h}}$ alongside 
the supermatrix include all the priority vectors derived for nodes that are parent nodes in the $\mathrm{C}_{\mathrm{h}}$ cluster.

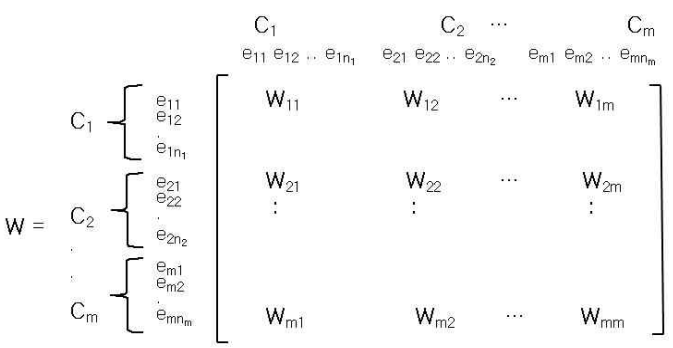

<Figure 2> Supermatrix of ANP(Saaty, 2005)

In earlier research, AHP has been used to determine the degree of importance of the customer needs (Park and Kim, 1998). Karsak et al. (2002) proposed ANP and Goal Programming (GP) model for product planning in QFD. They adopted a zero-one GP methodology that includes importance level of product requirements derived from the ANP. Liu and Hsiao (2006) integrated ANP and GP model for product variety design under budgetary constraints. They tried to find the drivers of the component variations to ensure the redesigned parts meeting the requirements of specialized niches in the segment markets. In the domain of supplier selection, ANP has been applied for the case study of electronic firm (Gencer and Gurpinar, 2007). Four clusters for decision making are business structure of the supplier, manufacturing capability of the supplier, quality system of the supplier and alternatives.

Service area attracts much attention in recent years. Lee et al. (2010) proposed an ANP approach for the evaluation of new service concepts (NSCs). The proposed approach measures feasibility of NSCs in terms of strategy, technology, market, implementation, and operation. The derived feasibility values of NSC alternatives are then employed to construct the NSC portfolio matrix, together with customers' preference. A case of the mobile information and entertainment service is presented to illustrate the proposed approach.

\section{Proposed Model}

\subsection{QFD and ANP Model}

A new methodology which is composed of QFD and ANP to transform CRs into product components and to find the priority of components for each PFs is proposed. The transformation of customer requirement into product component is implemented using QFD. <Figure 3> represents the structure of QFD.

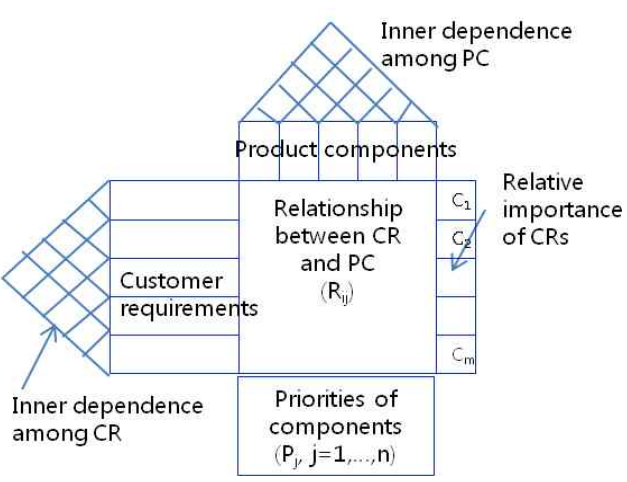

$<$ Figure 3> QFD and Its Components

In the Figure, priorities of product compo- 
nents $P_{j}$ are represented as the following.

$$
P_{j}=\sum_{i=1}^{m} C_{i} R_{i j}, j=1,2, \cdots, n
$$

This corresponds to the absolute priority importance of each product component. The relative importance of each component can be transformed into the following.

$$
P R_{j}=\frac{P_{j}}{\sum_{k=1}^{n} P_{k}}, \quad j=1,2, \cdots, n
$$

Product family design problem can be represented as a hierarchical structure composed of goal, customer requirement and components. If interdependence among criteria is assumed, it can be represented as ANP model. Dependence can occur within the clusters and between them. A control hierarchy at the top may be replaced by a control network with dependence among its clusters. $<$ Figure $4>$ (a) shows an ANP model with dependence among criteria (customer requirements and components).

The ANP model structure can be represented as a supermatrix as shown in $<$ Figure $4>$ (b). In general, we derive the limiting supermatrix as limiting priorities for the final influence of the components (Saaty, 1999, 2005). When a network consists of only two clusters apart from the goal, matrix manipulation approach can be adopted based on Saaty and Takizawa (1986), Lee and Kim (2000) and Karsak et al.
(2002). This research adopts the latter approach.

In the supermatrix structure, $\mathrm{W}_{21}$ represents relative importance weight of customer requirements to satisfy each market goal. $\mathrm{W}_{22}$ corresponds to the interdependence of customer requirements themselves. $\mathrm{W}_{32}$ means the influence of customer requirements into components. $\mathrm{W}_{33}$ corresponds to the interdependence of components themselves.

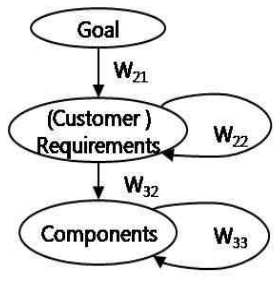

a. ANP model

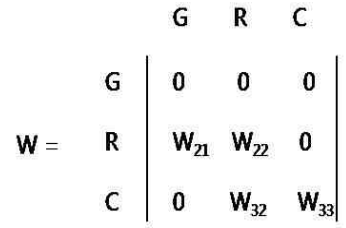

b. Supermatrix structure
<Figure 4> Supermatrix Formation

Using the notations given above, the interdependent priorities of customer requirements $\left(\mathrm{W}_{\mathrm{CR}}\right)$ are computed by multiplying $\mathrm{W}_{22}$ by $\mathrm{W}_{21}$.

$$
W_{C R}=W_{22} \times W_{21}
$$

The interdependent priorities of components $\left(\mathrm{W}_{\mathrm{C}}\right)$ are computed by multiplying $\mathrm{W}_{33}$ by $\mathrm{W}_{32}$

$$
W_{C}=W_{33} \times W_{32}
$$

The overall priorities of components $\left(\mathrm{W}_{\mathrm{G}}\right)$ are computed by multiplying $\mathrm{W}_{\mathrm{C}}$ by $\mathrm{W}_{\mathrm{CR}}$

$$
W_{G}=W_{C} \times W_{C R}
$$




\subsection{Procedures}

In order to apply the proposed model to the problem domain, the following three phases are proposed: product family analysis, ANP approach and analysis with QFD model. Phase 1 is a preprocessing stage. Product information is gathered and characteristics are compared for each product specification. Then the product is disassembled and each component is identified. Finally, market segmentation is performed and $\mathrm{PF}$ are grouped for each segment. Phase 2 performs major ANP steps. Variables defined in $<$ Figure $4>$ are calculated. The priority for each component corresponding to PFs is calculated. Phase 3 is analysis and comparison stage. To compare ANP results with those of QFD model, ANP process is conducted for the whole CRs without dividing into PFs. The priority of each component is compared with that of phase 2 . The framework of problem solving procedures is given in $<$ Figure $5>$.

\section{Product Family Analysis}

This research aims at developing a product family modeling to satisfy various customer requirements. As a problem domain, netbooks are chosen. Netbooks are smaller notebooks optimized for low weight and low cost. Netbooks are a branch of subnotebooks, sometimes also called mini notebooks or ultraportables. They are rapidly evolving category of small, light and inexpensive laptop computers suited for general computing and accessing web-based applications. Netbooks omitted certain features (e.g., the optical drive), featured smaller screens and keyboards, and offered reduced specification and computing power. Over the course of their evolution, netbooks have ranged in size from below 5 " screen diagonal to over 10.1", and from $\sim 1 \mathrm{~kg}(2 \sim 3$ pounds). The product specification of nine net-

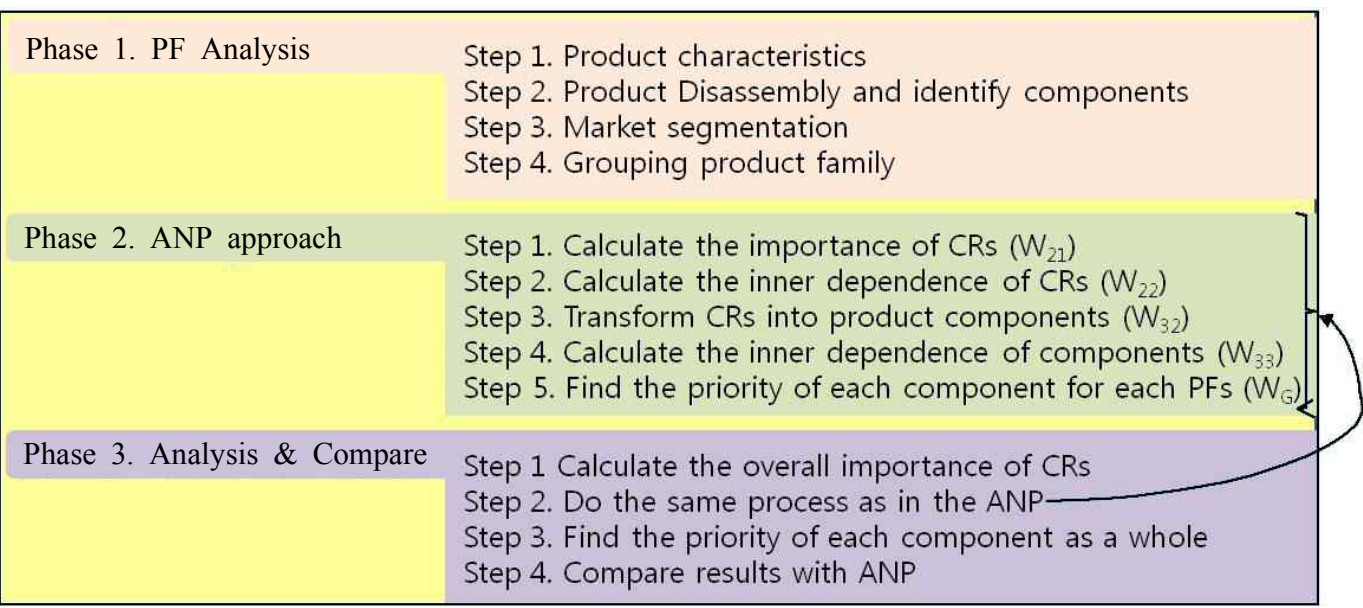

$<$ Figure 5> Phases and Steps for Applying the Proposed Model 
book products is compared in <Table $1>$.

From the table, all parameters are related to the netbook itself except the last column. The characteristics in the last column correspond to an artificial one in order to divide the nine products into three product families. For ease understanding, they are grouped into three categories from simple model to high-end model as PF1, PF2 and PF3.

In order to understand the product structure, a netbook is disassembled. Components of typical netbook product are given in $<$ Figure $6>$, and name of each component is provided in $<$ Table $2>$.

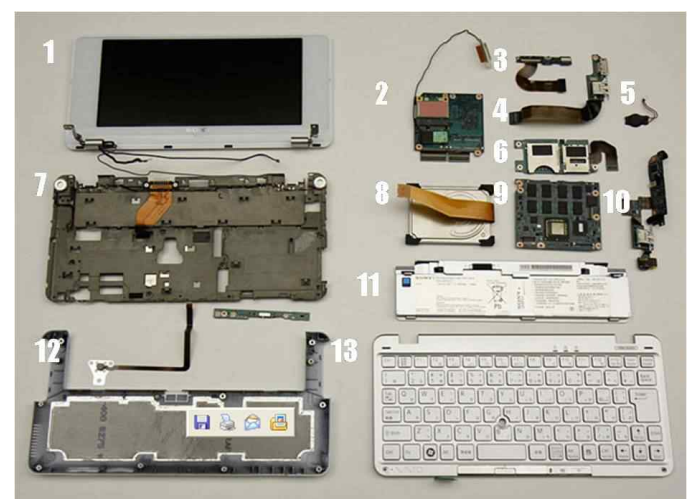

<Figure 6> Disassembled Components of Netbook

Market segmentation is an efficient method to be useful in the PF design. A market segment is a sub-set of a market made up of peo-

$<$ Table 1> Product Characteristics of Nine Netbook Products

\begin{tabular}{|c|c|c|c|c|c|c|c|c|c|}
\hline Model & Manufacturer & Image & $\mathrm{CPU}$ & Memory & HDD & Battery & Resolution & OS & PF \\
\hline Aspire one A0A110 & Acer & & $\begin{array}{c}\mathrm{N} 270 \\
(1.66 \mathrm{GHz})\end{array}$ & $512 \mathrm{MB}$ & 8GB(SSD) & 3cell & $1024 \times 600$ & $\begin{array}{l}\text { XP Home } \\
\text { Eng }\end{array}$ & PF1 \\
\hline $\begin{array}{c}\text { Fine force StormX } \\
\text { NB-101 }\end{array}$ & Fine force & & $\begin{array}{c}\mathrm{N} 270 \\
(1.66 \mathrm{GHz})\end{array}$ & $1 \mathrm{~GB}$ & $160 \mathrm{~GB}$ & 3cell & $1024 \times 600$ & No & PF1 \\
\hline WMC-81007 & Etc & & $\begin{array}{c}\mathrm{N} 270 \\
(1.66 \mathrm{GHz})\end{array}$ & $1 \mathrm{~GB}$ & $120 \mathrm{~GB}$ & 4000mAh & $1024 \times 600$ & $\begin{array}{l}\text { XP Home } \\
\text { KR }\end{array}$ & PF1 \\
\hline $\begin{array}{c}\text { SENS } \\
\text { NT-N150-KA51P }\end{array}$ & Samsung & & $\begin{array}{c}\mathrm{N} 450 \\
(1.66 \mathrm{GHz})\end{array}$ & $1 \mathrm{~GB}$ & $160 \mathrm{~GB}$ & 6cell & $1024 \times 600$ & $\begin{array}{l}\text { XP Home } \\
\text { KR }\end{array}$ & PF2 \\
\hline EEEPCC-1008HA & Asus & & $\begin{array}{c}\mathrm{N} 280 \\
(1.66 \mathrm{GHz})\end{array}$ & $1 \mathrm{~GB}$ & $160 \mathrm{~GB}$ & $\begin{array}{l}\text { Lithium } \\
\text { polymer }\end{array}$ & $1024 \times 600$ & $\begin{array}{l}\text { XP Home } \\
\text { KR }\end{array}$ & PF2 \\
\hline Aspire one D532h & Acer & & $\begin{array}{c}\mathrm{N} 450 \\
(1.66 \mathrm{GHz})\end{array}$ & $1 \mathrm{~GB}$ & $250 \mathrm{~GB}$ & 6cell & $1024 \times 600$ & $\begin{array}{l}\text { Windows7 } \\
\text { Starter }\end{array}$ & PF2 \\
\hline VAIO VPCX127LKIX & Sony & & $\begin{array}{c}Z 550 \\
(2.0 \mathrm{GHZ})\end{array}$ & $2 \mathrm{~GB}$ & $\begin{array}{l}\text { 128GB } \\
\text { (SDD) }\end{array}$ & $\begin{array}{l}\text { Lithium } \\
\text { polymer }\end{array}$ & $1366 \times 766$ & $\begin{array}{l}\text { Windows7 } \\
\text { professional }\end{array}$ & PF3 \\
\hline XNOTE X300-LR8CK & LG & & $\begin{array}{c}Z 550 \\
(2.0 \mathrm{GHZ})\end{array}$ & $1 \mathrm{~GB}$ & $\begin{array}{l}648 \mathrm{~GB} \\
\text { (SDD) }\end{array}$ & $\begin{array}{l}\text { Lithium } \\
\text { polymer }\end{array}$ & $1366 \times 766$ & $\begin{array}{l}\text { Windows7 } \\
\text { professional }\end{array}$ & PF3 \\
\hline VAIO VGN-P35LK/R & Sony & & $\begin{array}{c}Z 550 \\
(2.0 \mathrm{GHZ})\end{array}$ & $2 \mathrm{~GB}$ & $\begin{array}{l}\text { 64GB } \\
\text { (SDD) }\end{array}$ & $\begin{array}{l}\text { Lithium } \\
\text { polymer }\end{array}$ & $1366 \times 766$ & $\begin{array}{l}\text { Windows7 } \\
\text { Home } \\
\text { premium }\end{array}$ & PF3 \\
\hline
\end{tabular}


ple or organizations sharing one or more characteristics that cause them to demand similar product and/or services based on qualities of those products such as price or function. For the market segmentation analysis, product survey in the real market has been performed. $<$ Table $1>$ provides product characteristics of nine netbooks by classifying their characteristics. Starting from a simple product to a high end item, they are chosen and grouped into three product families. Three product families are assumed from low to high in performance and user group. The market segment and the positioning of three product families are given in $<$ Table $3>$.

\section{$<$ Table 2> Component Name}

\begin{tabular}{|cl|}
\hline Part no. & Component name \\
\hline 1 & Monitor \\
2 & Graphic card \\
3 & RAM \\
4 & ODD socket \\
5 & Power socket \\
6 & Power \\
7 & Cooler board \\
8 & Hard disk drive \\
9 & Main board \\
10 & LAN \\
11 & Battery \\
12 & Cover \\
13 & Key board \\
\hline
\end{tabular}

$<$ Table 3> Market Segment and Product Family

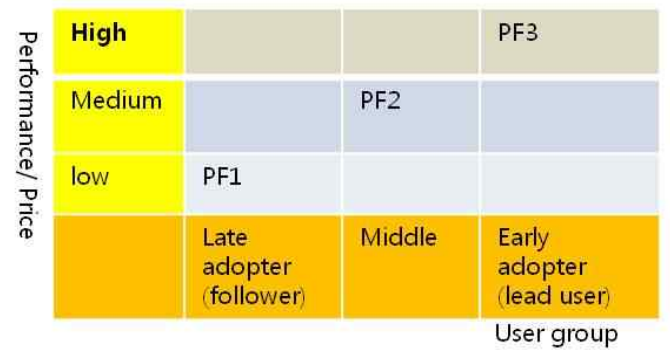

The best way to sell a new product is to know your customers. As netbook is an innovative product with fast changing features and short-life, the customer requirements have been surveyed and analyzed in the market segment. The customer needs and market positioning is given in $<$ Table $4>$.

$<$ Table 4> Customer Equirement and Product Family

\begin{tabular}{|lccc|}
\hline \multicolumn{1}{|c}{ Customer requirements } & PF1 & PF2 & PF3 \\
\hline Portability (PO) & $\mathrm{M}$ & & \\
Design(DE) & & & $\mathrm{H}$ \\
Battery capacity(BC) & & $\mathrm{H}$ & \\
Display resolution(DR) & & & $\mathrm{H}$ \\
Technical spec(TS) & & $\mathrm{M}$ & \\
Interface: Bluetooth, UBS (IN) & $\mathrm{L}$ & & \\
Price(PR) & $\mathrm{H}$ & & \\
\hline
\end{tabular}

Note) $\mathrm{L}$ is low, $\mathrm{M}$ is medium and $\mathrm{H}$ is high in requirements

\section{ANP approach}

The proposed model is implemented using the example problem of netbooks shown in Section 4. The process is as the following.

Step 1 : Calculate relative importance of customer requirements $\left(\mathrm{w}_{21}\right)$.

For each PF group, the relative importance of each $\mathrm{CR}$ is acquired from the market survey data. In $<$ Table $4>$, as the relative weight is evaluated for each cell in the market segment, it is transformed into numeric value shown in $\langle$ Figure $7>$. The cell with 0 value means that there is no impact on the cell even if there is any change in the CRs. 


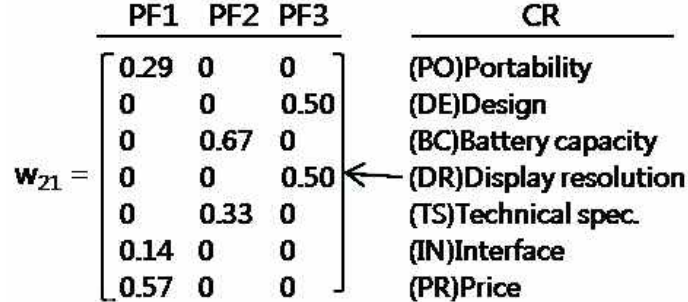

$<$ Figure 7> Importance of CRs for Each PF

Step 2: Calculate the inner dependence of CRs $\left(\mathrm{w}_{22}\right)$.

In the new product design process, inner dependences are observed among the CRs. Based on pairwise comparison by domain expert, eigenvectors can be acquired as $<$ Table $5>$. Each column represents impact degree of each $\mathrm{CR}$ to other CRs. For example, the $4^{\text {th }}$ column indicates that battery capacity (BC) has impact value of 0.29 on portability (PO) and technical spec (TS) with impact 0.14 .

$<$ Table 5> Inner Dependence of CRs ( $\left.\mathrm{W}_{22}\right)$

\begin{tabular}{|cccccccc|}
\hline CRS & PO & DE & BC & DR & TS & IN & PR \\
\hline PO & 0.57 & 0 & 0.29 & 0 & 0 & 0.29 & 0 \\
DE & 0.14 & 0.8 & 0 & 0 & 0 & 0.14 & 0.2 \\
BC & 0.29 & 0 & 0.57 & 0 & 0 & 0 & 0.2 \\
DR & 0 & 0 & 0 & 0.67 & 0 & 0 & 0 \\
TS & 0 & 0 & 0.14 & 0.33 & 0.67 & 0 & 0.2 \\
IN & 0 & 0 & 0 & 0 & 0.33 & 0.57 & 0 \\
PR & 0 & 0.2 & 0 & 0 & 0 & 0 & 0.4 \\
\hline
\end{tabular}

Step 3: Transform the CRs into the product component $\left(\mathrm{w}_{32}\right)$.

In this step, the CRs are transformed into product component by pairwise comparison using AHP. $<$ Table $6>$ shows the relative weights of "Portability" requirement with regard to product components.

$<$ Table 6> Relative Importance of Components for Portability $\left(w_{321}\right)$

\begin{tabular}{|lccccccc|}
\hline Component & MN & PW & LN & BT & CV & KB & Weight \\
\hline Monitor(MN) & 1.00 & 3.00 & 3.00 & 1.00 & 5.00 & 3.00 & 0.24 \\
Power(PW) & 0.33 & 1.00 & 0.33 & 0.14 & 5.00 & 1.00 & 0.12 \\
LAN(LN) & 0.33 & 3.00 & 1.00 & 0.20 & 5.00 & 3.00 & 0.19 \\
Battery(BT) & 1.00 & 7.00 & 5.00 & 1.00 & 5.00 & 3.00 & 0.33 \\
Cover(CV) & 0.20 & 0.20 & 0.20 & 0.20 & 1.00 & 0.33 & 0.03 \\
Keyboard(KB) & 0.33 & 1.00 & 0.33 & 0.33 & 3.00 & 1.00 & 0.09 \\
\hline
\end{tabular}

After all relative importance for all CRs are acquired through the process in $\langle$ Table 6$\rangle$, the transformation matrix is generated as $<$ Table $7>$.

$<$ Table 7> Column Eigenvectors of Components for each Customer Requirements $\left(W_{32}\right)$

\begin{tabular}{|cccccccc|}
\hline Component & PO & DE & BC & DR & TS & IN & PR \\
\hline 1 & 0.24 & 0.50 & 0.30 & 0.22 & 0.27 & 0 & 0.29 \\
2 & 0 & 0 & 0 & 0.31 & 0.13 & 0 & 0.14 \\
3 & 0 & 0 & 0 & 0.24 & 0.28 & 0 & 0.24 \\
4 & 0 & 0 & 0 & 0.04 & 0 & 0 & 0 \\
5 & 0 & 0 & 0 & 0 & 0 & 0 & 0 \\
6 & 0.12 & 0 & 0.07 & 0 & 0 & 0 & 0 \\
7 & 0 & 0.08 & 0 & 0 & 0 & 0 & 0 \\
8 & 0 & 0 & 0 & 0.12 & 0.27 & 0 & 0.10 \\
9 & 0 & 0 & 0 & 0.08 & 0.06 & 0.22 & 0.19 \\
10 & 0.19 & 0 & 0 & 0 & 0 & 0.70 & 0 \\
11 & 0.33 & 0 & 0.63 & 0 & 0 & 0 & 0.05 \\
12 & 0.03 & 0.09 & 0 & 0 & 0 & 0.08 & 0 \\
13 & 0.09 & 0.33 & 0 & 0 & 0 & 0 & 0 \\
\hline
\end{tabular}

Step 4 : Calculate component inner dependence (w33)

Within a product, two components are dependent when a small change in one component 
influences to another component. They may be loosely or tightly coupled. $<$ Figure $8>$ shows inner dependent diagram among components. Arrow represents design constraint from one component to another. For the product family design, the coupling relationship should be considered.

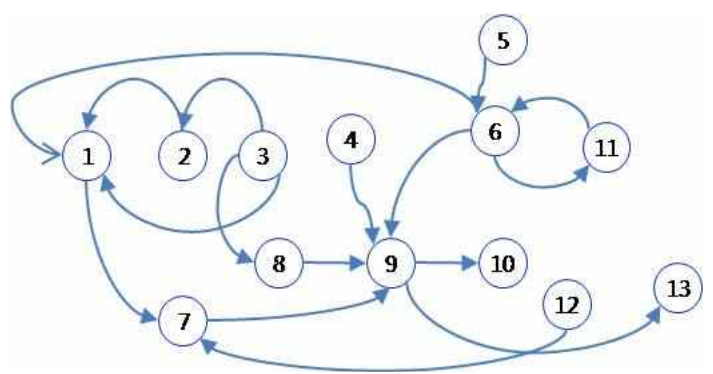

<Figure 8> Inner Dependence Diagram among Product Components

The inner dependencies of components can be calculated based on pairwise comparison among interacting components. For example, the inner dependency of component 1 is shown in $<$ Figure 9 $>$. Four other parts are related to the component 1 (monitor). Through a pairwise comparison, relative weight of related component is derived as $<$ Table $8>$.

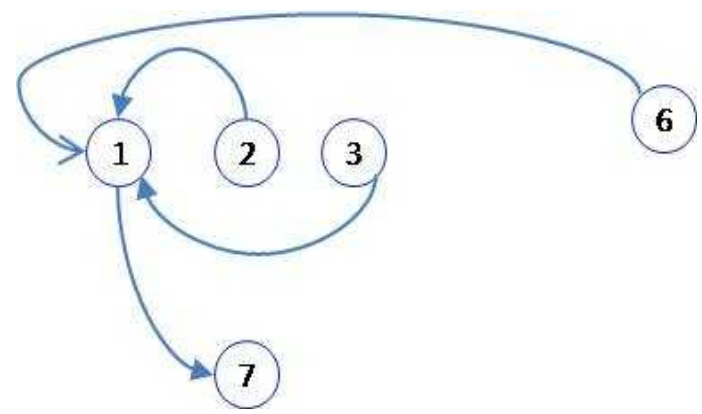

$<$ Figure 9> The Inner Dependency of Component 1
$<$ Table 8> The Inner Dependency Matrix Related to Component 1 (Monitor)

\begin{tabular}{|lcccccc|}
\hline & 1 & 2 & 3 & 6 & 7 & Weight \\
\hline Monitor(1) & 1.00 & 3.00 & 3.00 & 5.00 & 5.00 & 0.34 \\
Graphic crd (2) & 0.33 & 1.00 & 0.33 & 5.00 & 5.00 & 0.24 \\
Ram(3) & 0.33 & 3.00 & 1.00 & 5.00 & 5.00 & 0.29 \\
Power(6) & 0.20 & 0.20 & 0.20 & 1.00 & 0.33 & 0.04 \\
Cooler brd (7) & 0.20 & 0.20 & 0.20 & 3.00 & 1.00 & 0.09 \\
\hline
\end{tabular}

For all the components, relative weight is calculated and presented in $<$ Table $9>$. The cell with 0 value means that there is no inner dependence between two components.

$<$ Table 9> The Inner Dependency Matrix Related to Component $\left(\mathrm{w}_{33}\right)$

\begin{tabular}{|cccccccccccccc|}
\hline & 1 & 2 & 3 & 4 & 5 & 6 & 7 & 8 & 9 & 10 & 11 & 12 & 13 \\
\hline 1 & .34 & .54 & .46 & 0 & 0 & .33 & .46 & 0 & 0 & 0 & 0 & 0 & 0 \\
2 & .24 & .13 & .18 & 0 & 0 & 0 & 0 & 0 & 0 & 0 & 0 & 0 & 0 \\
3 & .29 & .33 & .28 & 0 & 0 & 0 & 0 & .54 & 0 & 0 & 0 & 0 & 0 \\
4 & 0 & 0 & 0 & .17 & 0 & 0 & 0 & 0 & .09 & 0 & 0 & 0 & 0 \\
5 & 0 & 0 & 0 & 0 & .25 & .04 & 0 & 0 & 0 & 0 & 0 & 0 & 0 \\
6 & .04 & 0 & 0 & 0 & .75 & .09 & 0 & 0 & .03 & 0 & .17 & 0 & 0 \\
7 & .09 & 0 & 0 & 0 & 0 & 0 & .07 & 0 & .06 & 0 & 0 & .50 & 0 \\
8 & 0 & 0 & .07 & 0 & 0 & 0 & 0 & .13 & .12 & 0 & 0 & 0 & 0 \\
9 & 0 & 0 & 0 & .83 & 0 & .22 & .28 & .33 & .32 & .83 & 0 & 0 & .75 \\
10 & 0 & 0 & 0 & 0 & 0 & 0 & 0 & 0 & .15 & .17 & 0 & 0 & 0 \\
11 & 0 & 0 & 0 & 0 & 0 & .32 & 0 & 0 & 0 & 0 & .83 & 0 & 0 \\
12 & 0 & 0 & 0 & 0 & 0 & 0 & .18 & 0 & 0 & 0 & 0 & .50 & 0 \\
13 & 0 & 0 & 0 & 0 & 0 & 0 & 0 & 0 & .22 & 0 & 0 & 0 & .25 \\
\hline
\end{tabular}

Step 5 : Find priority of components for product family.

The interdependent priorities of customer requirements $\left(\mathrm{W}_{\mathrm{CR}}\right)$, priorities of product components $\left(\mathrm{W}_{\mathrm{C}}\right)$, and overall priorities $\left(\mathrm{W}_{\mathrm{G}}\right)$ are derived based on equation $(3) \sim(5)$. 
The priorities of customer requirements $\left(\mathrm{W}_{\mathrm{CR}}\right)$ are computed by multiplying $\mathrm{W}_{22}$ by $\mathrm{W}_{21}$ $: \mathrm{W}_{\mathrm{CR}}=\mathrm{W}_{22} \times \mathrm{W}_{21}$.

$<$ Table 10> The Interdependent Priorities of Customer Requirements $\left(W_{C R}\right)$

$W_{C R}=\left|\begin{array}{lll}0.21 & 0.19 & 0.00 \\ 0.17 & 0.00 & 0.40 \\ 0.20 & 0.38 & 0.00 \\ 0.00 & 0.00 & 0.34 \\ 0.11 & 0.31 & 0.17 \\ 0.08 & 0.11 & 0.00 \\ 0.23 & 0.00 & 0.10\end{array}\right|$

The interdependent priorities of components $\left(\mathrm{W}_{\mathrm{C}}\right)$ are computed by multiplying $\mathrm{W}_{33}$ by $\mathrm{W}_{32}: \mathrm{W}_{\mathrm{C}}=\mathrm{W}_{33} \times \mathrm{W}_{32}$.

$<$ Table 11> The Inter Dependent Priorities of
$W_{c}=\left|\begin{array}{lllllll}0.12 & 0.21 & 0.13 & 0.35 & 0.29 & 0.00 & 0.28 \\ 0.06 & 0.12 & 0.07 & 0.14 & 0.13 & 0.00 & 0.13 \\ 0.07 & 0.15 & 0.09 & 0.30 & 0.35 & 0.00 & 0.25 \\ 0.00 & 0.00 & 0.00 & 0.01 & 0.01 & 0.02 & 0.02 \\ 0.00 & 0.00 & 0.00 & 0.00 & 0.00 & 0.00 & 0.00 \\ 0.08 & 0.02 & 0.13 & 0.01 & 0.01 & 0.01 & 0.03 \\ 0.04 & 0.10 & 0.03 & 0.02 & 0.03 & 0.05 & 0.04 \\ 0.00 & 0.00 & 0.00 & 0.04 & 0.06 & 0.03 & 0.05 \\ 0.25 & 0.27 & 0.02 & 0.10 & 0.11 & 0.65 & 0.09 \\ 0.03 & 0.00 & 0.00 & 0.01 & 0.01 & 0.15 & 0.03 \\ 0.31 & 0.00 & 0.55 & 0.00 & 0.00 & 0.00 & 0.04 \\ 0.02 & 0.06 & 0.00 & 0.00 & 0.00 & 0.04 & 0.00 \\ 0.02 & 0.08 & 0.00 & 0.02 & 0.01 & 0.05 & 0.04\end{array}\right|$

The overall priorities of components $\left(\mathrm{W}_{\mathrm{G}}\right)$ are computed by multiplying $\mathrm{W}_{\mathrm{C}}$ by $\mathrm{W}_{\mathrm{CR}}$ : $\mathrm{W}_{\mathrm{G}}$
$=\mathrm{W}_{\mathrm{C}} \times \mathrm{W}_{\mathrm{CR}}$.

$<$ Table 12> The Overall Priorities of Components (WG)

\begin{tabular}{c|lll|l}
\multicolumn{1}{c}{ PF1 } & PF2 & \multicolumn{1}{c}{ PF3 } & \multicolumn{1}{c}{ Components } \\
\hline WG $=$ & 0.18 & 0.16 & 0.28 & Monitor \\
0.09 & 0.08 & 0.13 & Graphic card \\
0.15 & 0.15 & 0.24 & RAM \\
0.01 & 0.00 & 0.01 & ODD socket \\
0.00 & 0.00 & 0.00 & Power socket \\
0.05 & 0.07 & 0.02 & Power \\
0.05 & 0.03 & 0.06 & Cooler board \\
0.02 & 0.02 & 0.03 & HDD \\
0.19 & 0.16 & 0.17 & Main board \\
0.03 & 0.03 & 0.01 & LAN \\
0.18 & 0.27 & 0.00 & Battery \\
0.02 & 0.01 & 0.02 & Cover \\
0.03 & 0.01 & 0.05 & Key board
\end{tabular}

The final result shows the priority weight of product components in each PF group. In the case of $\mathrm{PF} 1$, higher priority appears in Main board, Monitor, Battery and RAM by a descending order. In the case of PF2, higher priority is shown in Battery, Monitor, Main board and RAM. In the case of PF3, higher priority appears in the order of Monitor, RAM, Main board, and Graphic card. In all PFs, Monitor, RAM, Main board have higher priority.

In the PF3, Battery does not show priority. Instead, the priority of Graphic card and RAM appears high compared to PF1 and PF2. This is related to the $\mathrm{CR}$ for the $\mathrm{PF}$. The interests from PF3 are more focused on design and display resolution. That's why PFs has low weight in battery and high in Graphic card and RAM. 


\section{Result Analysis}

The final result from ANP analysis is compared with that of QFD approach. In this research, customer requirements are divided into product family groups based on market segmentation. ANP has been performed based on the divided PFs. The overall priority, $\mathrm{W}_{\mathrm{G}}$ in the previous section shows the priority of component for each PF.

To validate the results, comparative experiment has been performed by calculating the overall priority of components without dividing into PFs. Assuming that there is no dependence

$$
\text { Priority }=\left[\begin{array}{c}
P O \\
D E \\
B C \\
D R \\
T S \\
I N \\
P R
\end{array}\right]=\left[\begin{array}{l}
0.10 \\
0.17 \\
0.22 \\
0.17 \\
0.11 \\
0.05 \\
0.19
\end{array}\right]
$$

$<$ Figure 10> Priority for the CRs without Dividing PFs

among the CRs, the eigenvectors for the CRs is obtained as $<$ Figure $10>$. The overall absolute and relative priority given in equation (1) and (2) are calculated following the process of equation (3) (5). <Figure 11> shows results from

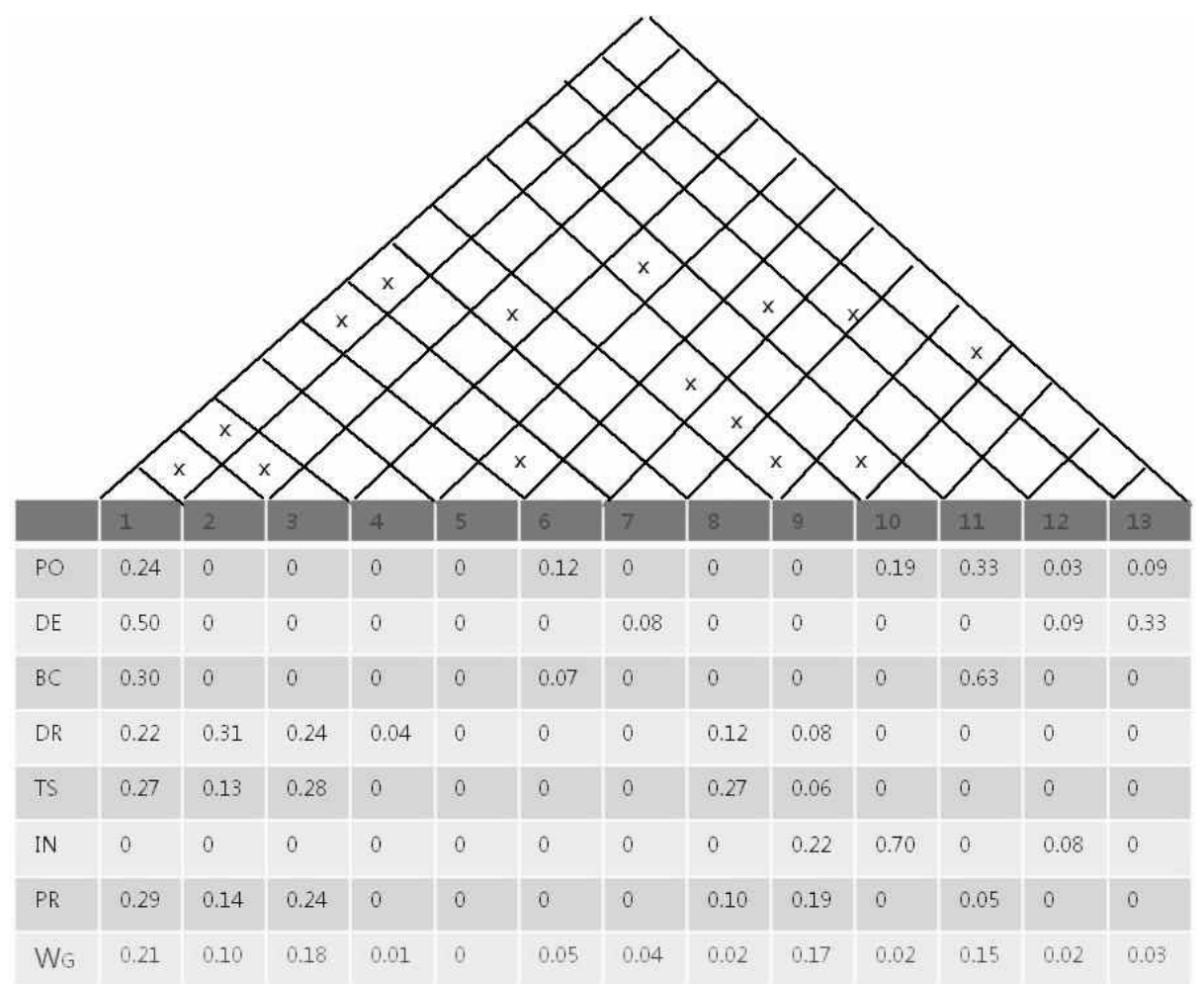

<Figure 11> QFD Matrix Result from ANP Methods 
ANP model corresponding to the structure in $<$ Figure $3>$ without dividing PFs. The relationship $R_{i j}$ between $\mathrm{CR}$ and $\mathrm{PC}$ is derived from $\mathrm{W}_{32}$. The inner dependence among PCs on the top of QFD is based on inner dependence diagram shown in $<$ Figure $8>$.

The overall priorities of each PCs are shown in the bottom row as $\mathrm{W}_{\mathrm{G}}$. Among 13 components of netbook, $<$ Figure $10>$ represents higher priorities in monitor, RAM, main board, and battery. This result agrees with the ANP model results from the divided PF groups shown in $<$ Table $11>$.

\section{Conclusions}

In this research, a methodology to design product family using ANP and QFD is presented and a thorough implementation has been performed. After the customer requirements are identified, they are positioned in the different market segments which are modeled as three PFs. The interdependence between CRs and PCs and among PCs are evaluated then analyzed using the ANP model. The proposed method is implemented for a product family of netbooks. The results derived from PF group are compared with those which are not divided into PF group. The two results represent similar priorities among the product components.

The proposed framework combining QFD and ANP for product family design is expected to be adopted in new product design process. It is capable of capturing the customer requirements, analyzing market segment, and mapping customer requirements to design parameters. In the company, this idea can be utilized for the resource allocation in order to prioritize the requirements and available resources.

Further research directions are as follows. First, model sensitivity should be tested and verified. Pairwise comparison is highly dependent on the person who evaluates the attributes. Even though we try to get data from the domain expert in the evaluation process, the result highly depends on the response from the expert. It is required to get multiple responses from several experts. Second, when analyzing actual product, there are many components in a subproduct. In this case, it is recommended to reduce the number of components to analyze through the preprocessing. In case of this research, component 4 and 5 , or even 8 and 10 can be omitted to analyze the ANP process. Through this process, we can concentrate on the important components and their relationships in detail. Third, as the life cycle of consumer electronic products is so short, the CRs for these products change quickly. Continued research is required using the updated CRs for the new product in this area.

\section{References}

Chang, Y., "Product value evaluation models based on itemset association chain", Journal of Intelligence and Information Systems, Vol.16, No.2(2010), 1 17 .

Cho, Y. and J. Bang, "Social network analysis 
for new product recommendation", Journal of Intelligence and Information Systems, Vol.15, No.4(2009), 177 193.

Gencer, C. and D. Gurpinar, "Analytic network process in supplier selection : A case study in an electric firm", Applied Mathematical Modeling, Vol.31(2007), 2475 2486.

Karssak, E., S. Sozer, and S. Alptekin, "Product planning in quality function deployment using a combined analytic network process and goal programming approach", Computers and Industrial Engineering, Vol.44(2002), $171 \sim 190$.

Kim, H., J. Kim, and Q. Y. Chen, "A network approach to derive product relations and anayze topological characteristics", Journal of Intelligence and Information Systems, Vol.15, No.4(2009), 155 176.

Kim, K. and D. Kim, "Research Issues in Robust QFD”, Industrial Engineering and Management Systems, Vol.7, No.2(2008), 93 100.

Kim, T., "Product variety modeling based on formal concept analysis", Industrial Engineering and Management Systems, Vol.9, No.1 (2010), $1 \sim 9$.

Kuang, J. and P. Jiang, "Product platform design for a product family based on Kansei engineering", Journal of Engineering Design, Vol.20, No.6(2009), 589 607.

Lee, H., C. Kim, and Y. Park, "Evaluation and management of new service concepts : An ANP-based portfolio approach", Computers and Industrial Engineering, Vol.58, No.4 (2010), 535 543 .

Lee, J. W. and S. H. Kim, "Using analytic network process and goal programming for interdependent information system project selection", Computers and Operations Research, Vol.27(2000), 367 382 .
Liu, E. and S.-W. Hsiao, "ANP-GP approach for product variety design”, Int. J. Advanced Manufacturing Technology, Vol.29(2006), $216 \sim 225$

Luo, X. G., C. K. Kwong, and J. F. Tang, "Determining optimal levels of engineering characteristics in quality function deployment under multi-segment market", Computers and Industrial Engineering, Vol.59, No.1(2010), $126 \sim 135$.

Martin, M. V. and K. Ishii, "Design for variety : developing standardized and modularized product platform architectures", Research Engineering Design, Vol.13(2002), 213 235.

Park, T. and K. Kim, "Determination of an optimal set of design requirements using house of quality", Journal of Operations Management, Vol.16(1998), 569 581.

Saaty, T. L., "Fundamentals of the analytic network process", ISAHP 1999, Kobe, Japan, (1999), $1 \sim 14$.

Saaty, T. L., Theory and Application of the Analytic Network Process, RWS publications, 2005.

Saaty, T. L. and M. Takizawa, "Dependence and independence : from linear hierarchies to nonlinear networks", ISAHP European Journal of Operational Research, Vol.26 (1986), 229 237.

Simpson, T. W., R. A. Maier, and F. Mistree, "Product Platform Design : method and application", Research Eng Design, Vol.13 (2001), 2 22.

Simpson, T. W., Z. Siddique, and J. Jiao Eds., Product Platform and Product Family Design : Methods and Applications, Springer, New York, (2005), 1 15. 


\section{Abstract}

\section{Analytic Network Process에 기초한 제품가족 디자인}

김태운

오늘날 글로벌한 경쟁에서 고객의 만족도를 유지하고 생산성과 효율을 높이기 위해서 대량맞춤(mass customization)이 많은 선도기업에서 채택되고 있다. 대량맞춤은 제품가족과 제품 플랫폼에 근거하여 기 업으로 하여금 새로운 제품을 유연하고 효율적이며 고객 요구에 신속히 대응하는 것을 용이하게 한다. 따라서 제품 플랫폼에 기반한 제품가족 전략이 대량맞춤을 실현화하는데 적절한 방법이다. 제품가족이란 다양한 시장의 요구를 충족하기 위해서 공통의 특성, 구성부품, 서브 시스템을 공유하는 일련의 유사한 제품군으로 정의된다. 이 연구의 목표는 제품가족 설계 전략을 이용하여 고객의 요구를 충족시키는 제품 의 구성부품간의 우선순위를 찾아내고자 하는 것이다. 신 제품 개발을 위한 의사결정 과정은 피드백을 가지는 다 변량 의사결정 모형을 필요로 한다. 이를 위해서 분석적 네트워크 과정(analytic network process) 방법을 이용하여 의사결정 모델과 절차를 수립하였다. 구현을 위해서 제품가족 모델에 적합한 소형 $\mathrm{PC}$ 인 넷북 제품을 선정하고, 각 제품가족에 대한 구성부품에 대하여 제안된 방법에 따라서 우선순 위를 도출하였다. 구현결과를 QFD 모델을 이용하여 고객요구사항과 구성부품간의 관계를 분석하고 평 가하였다.

Keywords : 제품가족, 대량맞춤, $\mathrm{ANP}, \mathrm{QFD}$, 신제품 개발

* 경성대학교 산업경영공학과 교수

16 지능정보연구 제17권 제4호 2011년 12월 


\section{저 자 소 개}

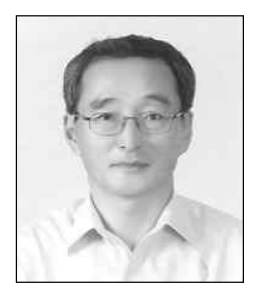

김태운

현재 경성대학교 산업경영공학과 교수로 재직 중이다. 서울대학교 산업공학과에 서 학사, 한국과학기술원 경영과학과에서 석사, 펜실베니아 주립대학교 산업공학 과에서 박사학위를 취득하였다. 2011년도에 미국 NIST Systems Integration Division에 방문교수를 역임하였다. 관심분야는 제품가족설계, 온톨로지 모델링, Supplier Discovery 등이다. 